DOI: http://doi.org/10.4038/ss.v49i1.4715

\title{
Effect of Government Bailouts on the Bank Performance and Risk Taking within Bailed out Banks
}

\author{
Thilini N. Jayasinghe 1
}

\begin{abstract}
During the global financial crisis, several banks all over the world were distressed due to the negative effects of the crisis. In order to mitigate the systemic risk, governments were under severe pressure to intervene in the financial industry in the form of government bailouts. However, these massive government bailout programmes created the debate whether the aftermath effects are positive or negative to the financial system. This paper focuses on finding the effects of government bailouts on the bailed out banks in terms of performance and risk taking during the post bailout period. It is found that government bailout has a significant negative impact on performance, while there is a significant positive relationship between bailout capital and the bank risk taking during the post bailout period.
\end{abstract}

Key Words: Government bailouts, bank performance, bank risk taking, bailout capital

JEL Classification: G21; H11; H12

\footnotetext{
${ }^{1}$ The author is currently serving as a Senior Assistant Director of the Risk Management Department. Corresponding email: thilini.jayasinghe@cbsl.lk. The author wishes to thank Professor Emmanuel Mamatzakis of the University of Sussex, UK for his valuable advice and guidance. Further, the author is thankful to the anonymous reviewers for their comments and advice. The views presented in this paper are those of the author and do not necessarily indicate the views of the Central Bank of Sri Lanka.
} 


\section{Introduction}

When considering the global context, the sub-prime mortgage crisis, which evolved in the US in 2007, severely affected the financial system stability around the globe, notably in the European region. The downturn in the financial sectors of the US, UK and Europe severely affected financial systems of international scale all over the world and led the global financial crisis. Due to the unrivalled scale of this crisis the real global economy was severely damaged, making large losses since the great depression. There was a dramatic decline in the value of assets including real estate and commodity prices, caused by the collapse of a number of large banks and other financial institutions, increasing the level of unemployment. The situation led governments all over the world to seek for ways and means to drive their countries out of the crisis (Moshirian, 2011).

When the global financial crisis aggravated, several banks all over the world ran down, creating a negative outlook on the global economy, where the governments were attempting to rescue their banks and other affected sectors of the economies. Many governments offered bailout packages including asset protection schemes, asset backed security schemes as well as corporate guarantees to the depositors of distressed institutions as a way of fighting back a systemic crisis. Nationalisation programmes were conducted as a response to the crisis, where governments bought partial or full ownership of some banks and financial institutions. Further, governments introduced prudential regulations for the financial industry, demanding a pro-active role from central banks as the financial sector regulator (Moshirian, 2011).

Financial crises have a significant negative effect on growth, irrespective of the fact that the financial system is developed or not (Kroszner et al., 2007). Banks and other financial institutions are the main financial intermediaries within a financial system that allow credit creation. When there's a failure in these intermediaries, where the presence of such intermediaries is important, there will be a contractionary impact on the whole financial system due to its high reliance (Kroszner et al., 2007). In order to overcome the negative effects, there were massive scale government interventions with large volume of government support in terms of capital being flowed in to the distressed banks (Hryckiewicz, 2014). However, the massive scale government bailouts created the debate whether they will serve the purpose of dramatic recovery in the financial sector or create further problems to the financial system stability of a country. In that sense, studying the effects of government interventions in the bailed-out banks will have macro-economic importance. 


\section{Literature review}

\subsection{Government intervention in the banking industry}

The subprime mortgage crisis that started in the US, was a catalyst for the systemic financial crisis that provoked in several countries around the globe, including the UK as well as the European Union. The severe effects on the domestic financial systems required the national governments, intervention and rescue of fleets of entities to reduce the aftermath effects of systemic crises. The main focus was on the financial sector, where a large number of distressed banks had to be rescued by national governments implementing several strategies, to secure the financial system stability.

According to Fahri and Tirole (2012), the mechanism of bailout is divided into two main strategies,

1. Focusing on the entire financial system, systemic remedies offered to all institutions disregarding level of effect on the crisis, which can be policy measures such as interest rate management.

2. Individual policy measures aiming at a particular bank or financial institution severely affected by the crisis, by deploying a significant amount of state resources such as tax revenue.

When looking at how banks have been bailed out by governments, there are several types of bailout instruments that are used based on the severity of the crisis. These instruments can be categorised as; credit guarantee schemes at the initial stages of the crisis, when the confidence on the banking system is uncertain. Then, the capital injections in the form of special liquidity schemes were used at the peak, where there are bank runs as explained in Diamond and Dybvig (1983). Special liquidity schemes are important in order to avoid the contagion effect while increasing the confidence towards the banking system, avoiding the crisis spreading to other healthy institutions, reducing value of the whole banking system. Asset protection schemes and asset backed security schemes are used at the final stages of the crisis as remedial measures (Pazarbasioglu et al., 2011; NAO, 2010). When the government does not have enough liquidity to bail out a bank through capital injections, it will be optimal to use a government assisted merger or acquisition (Acharya \& Yorulmazer, 2007). Hryckiewicz, (2014) identified that the most common type of bailout measure in the recent financial turmoil was nationalisation through capital injections, where the ownership was transferred to the government. During the recent history, most banks that were nationalised were systemically important global banks. Further, in asset protection schemes, the government will secure the bad debt up to the value of asset decreased, allowing the bank to recapitalise itself for survival. For this strategy to be successful, market discipline should be in place, as the government will not participate in bank operations (Ratnovski et al., 2012). 


\subsection{Government policy implications relating to interventions}

Government safety net is an important factor for the financial system stability of a country. The importance of government safety net was highlighted during the outbreak of the recent financial crisis where several governments were acting as lenders of last resort, implementing bailout policies to secure the financial systems of the countries. According to Gorton and Metrick (2013), in order to mitigate the risk of a liquidity driven crisis in the financial system, two pillars, being lender of last resort and deposit insurance have been implemented. The incentives for the banks may shift with the expectation of the functioning of the government safety net, where the banks can take higher risk seeking strategy for a higher return. This implication leads to the rationale of close supervision and regulation, which limits leverage and risk taking of the financial institutions.

Central Banks play a vital role in financial regulation particularly in the government safety net, while providing the lender of the last resort facility through the provisioning of contingent liquidity to the banks. Under the perfect market conditions, depositor's expectation in a systemic crisis will be that the Central Banks would lend freely to safeguard the problem institutions while letting the institutions fail outside of crisis, where there are incentives for a bank run. In order to establish the credibility within the financial system, avoiding systemic failures is an important implication for a Central Bank on behalf of a government (Dooley, 2014; Gorton and Metrick, 2013; Lacker, 2014).

Gorton and Metrick (2013) further highlights two dynamic and complex implications of the government safety net, as if the safety net is too large, then the banks will lose the incentive of managing the risk, which in turn leads to moral hazard behaviour. On the other hand, if the safety net is too small, possible failures of larger banks may systemically create a threat to the financial system as a whole, due to the spill over effect. Considering the fact, if larger banks and larger financial institutions are to be given complete protection, then there will be motivation in the industry for every financial institution to be grown into a 'too-big-to-fail' financial institution, which has to be safe guarded by the governments during a crisis, even at a very high cost (Barth \& Schnabel, 2013). Demirgüç-Kunt and Huizinga (2013) however realise that due to the deterioration of public financing, the ability to bailout the too-big-tofail is questionable around the world, especially in countries running with larger deficits and fiscal imbalances. Further, they argue that it is vital for regulatory measures such as downsizing or splitting up to be systemically important banks, as the value of such banks can be improved while reducing the risk of converting in to too-big-to-fail.

Moreover, according to Acharya and Yorulmazer (2007) 'too-many-to-fail-effect' exists in the regulation context. Too many to fail effect has been defined by Allen and Gale (2000) cited in Brown and Dinç (2011) as "Regulators may choose not to take over or close a failing bank if there are many weak banks. Alternatively, there may be reasons for aggressive regulatory intervention in failing banks when the banking system is weak, precisely because of concerns 
about systemic risk". Brown and Dinç (2011) found that this argument is robust even after several macroeconomic and crisis related factors such as too-big-to-fail effect and systemic risk are being controlled. Discussed policy implications will always affect the severity of government decision making regarding the intervention in the banking industry as a whole.

\subsection{Government bailouts and practical implications}

Government bailout in the banking industry is conducted with the objective of restoring market confidence and preventing the happening of a systemic banking crisis (Mehran \& Thakor, 2011). However, the bailout policies can sometimes end up in moral hazard behaviour of the banks due to the classic problem of information asymmetry (Yiannaki, 2011). There are several practical implications relating to the process of government intervention in the banking industry. "Too-big-to-fail rule vs too-many-to-fail rule" is one of the most important implications. The too-big-to-fail problem will affect the large banks, while the too-many-tofail effect will have significant implications on the smaller banks. This is where, at the failure of one bank, there will be several other banks, which will face difficulties in an economy (Yiannaki, 2011). Although, the main objective of bailout is stability, it will not always be achieved, as the governments will favour underperforming entities by safeguarding their assets at a high social cost in the long term.

\subsection{Government bailouts and bank behaviour}

Theoretically, government intervention in the banking industry should reflect desired outcomes, such as the confidence in the banking sector including the restoration of the overall credit system and prevention of the contagion effect of crisis causing an economic recession. Regulatory procedure will help the distressed institutions to recover and shape up the bank behaviour through market discipline. (Berger et al., 2016; Mehran \& Thakor, 2011). Further, stronger regulatory compliance may discipline the behaviour of bank management while strengthening the bank's monitory incentives (Dam \& Koetter, 2012; Mehran \& Thakor, 2011; Ratnovski et al., 2012).

On the other hand, it is argued that bailout policy measures cause more harm to the banking sector than good. According to Dam and Koetter (2012), bailout measures will increase the moral hazard behaviour in the banking industry due to the anticipation of bailout and the drastic reduction in market discipline. Gropp et al., (2011) further argue that bailout policy measures will distort the market competition in the banking industry, increasing the risk faced by the market participants, especially non-assisted once. However, Dam and Koetter (2012) have found evidence during their study, that moral hazard behaviour due to government safety net, can be mitigated through a thorough supervisory review mechanism in the banking industry. Although there is expectation that government bailouts will restore the value of distressed banks, there is evidence that it will not be the case always. Giannetti and Simonov (2013) argue that bailout packages are not always large enough to completely improve the 
financial condition of the problem banks as the bailout will not accompany an efficient restructuring of the problem bank's statement of financial position. Fahri and Tirole (2012) identified that bailout regulatory policy will lead to collective moral hazard problems due to the cheap capital available to problem banks; they will invest in high-risk assets, increasing borrowings while reducing liquidity. Further, O'hara and Shaw (1990) found that due to the concept of "too-big-to-fail", big banks would tend to seek for higher risk than the smaller, as they are covered completely by government deposit insurance schemes. Gropp et al. (2011) emphasised on the importance of ownership structure to bank behaviour, as the government owned banks pursue high-risk investments more than privately owned banks. However, Dam and Koetter (2012) mentioned that political influence is also a strong element for bank bailouts and the subsequent bank behaviour will depend on the policies used to bailout the banks.

\subsection{Impact of government bailouts on bank performance}

Studies have been conducted measuring the performance of the banks during the financial crisis. Beltratti and Stulz (2012) found that during the recent financial crisis, bank performance was affected severely, due to the fragility of the banking system, as the banks were financed with short term capital market funds. During the time, better performing banks were equipped with less leverage and lower returns in the pre-crisis era. However, they argue that local bank regulations were not correlating with the bank performance during the crisis. Berger and Bouwman (2013) further found that small banks would be benefited from capital, as capital increases the probability of survival and market share, while enhancing the performance of larger and medium banks. Bertay et al. (2013) argue that bank performance may vary with the bank's choice of risk and return, the size of the bank, its funding mix and activity strategy. Grigorian and Manole (2006) further identified the effects of foreign ownership and powerful restructuring, which include enhancing bank efficiency and performance. They also assert that prudential tightening will vary with the prudential norms specific to the country of the bank and bank consolidation will improve performance.

Several techniques have been mentioned in prior literature relating to measuring the bank performance, including techniques such as data envelopment analysis and stochastic frontier analysis. However, Yeh (1996) found that financial ratios can be used to evaluate the quality of the management as well as financial performance of a bank although there is a disadvantage of ratios where single ratios need to be compared with benchmarks. Such ratios can be "capital adequacy, earnings, liquidity and deposit growth" (Yeh, 1996). Further Kumbirai and Webb (2010) confirm the usage of financial ratios in measuring the performance as well as the risk of a bank by using profitability, liquidity and credit quality performance ratios in their study, which measured the bank performance and risk during the recent financial turmoil. 


\subsection{Impact of government bailouts on bank risk taking}

Effects of government bailout on bank behaviour will depend on the strategies used by the governments for the bailout and the policy mechanisms of the assisted banks (Dam \& Koetter, 2012). Hakenes and Schnabel (2010) analysed the competitive effects on government bailout policies in the banking industry and found that bailout promotes low risk taking in the assisted banks and high risk taking within its competitor banks. They explain this phenomenon as, when the bailout measures increase the prospects of the assisted bank to expand, the competition within the industry will put pressure on the other bank margins, finally resulting in high risk taking within the industry. Based on ex-post observations, Demirgüç-Kunt and Huizinga, (2013); Gropp et al. (2011) mention that deposit insurance would promote high-risk behaviour within the banking industry, associated with moral hazards, although the expectation is that the capital access will reduce the risk-taking incentives of the protected banks.

However, some controversial results also have been found when studying the effects of bank bailout procedures in the bank risk taking. Berger et al. (2016) found that government capital injections to bailout a problem bank would improve the capital ratios of the bank without affecting the bank risk, regardless of the size of the bank. In contrast, Duchin and Sosyura (2014) argue that after receiving government assistance, bailed-out banks will create high risk loans, shifting the portfolio towards high risk securities. Since risk shifting is mostly within the same asset class, they will not be diagnosed by regulatory capital ratios, which then indicate improved capitalisation as appearing safe, while increasing default risk and volatility. Further, Black and Hazelwood (2013) found that size of the bank has an impact on risk taking behaviour. Larger banks will shift towards high risk taking, without increasing lending, due to moral hazards after government intervention, while the smaller banks try to reduce the risk of lending after government support. Black and Hazelwood (2013) further argue that risk taking has moved in different directions possibly due to the conflicting goals of the bailout programme.

Moreover, Hryckiewicz (2014) found that there is a strong correlation between the subsequent increase of risk in the banking sector and government interventions with a strong magnitude of the effect. It is argued that increasing risk is a result of inappropriate restructuring, inefficient management of banks as well as withdrawal of the governance mechanisms during the post intervention period. When there are extensive bailout programmes then there will be higher risks in the subsequent periods. Further to the moral hazard problem, the important role played by the government in the banking sector may encourage the self-interest of politicians, further leading to poor performance and higher risk in the bailed-out banks due to the unavailability of a proper restructuring mechanism (ibid:2014).

When analysing empirical evidence, there were very few research studies, that had been conducted in relation to the effects of government intervention in the banking sector of UK 
and Europe. However, the author could not find evidence from the previous research studies conducted on the effects on performance and risk taking of bailed out banks due to government bailouts during the subsequent period of crisis.

Therefore, the purpose of this study is to fill the research gap by identifying the effects on performance and risk taking during the post bailout period in bailed out banks and provide valuable information to the markets, regulators and governments regarding the true effects of government interventions, by identifying the ways and means of overcoming or reducing the negative outcomes.

Accordingly, the research questions were developed as follows;

1. What is the effect of government bailouts reflected in the performance of bailout banks, during the post bailout period?

2. What is the effect of government bailouts in the risk-taking behaviour of the bailout banks, during the post bailout period?

\section{Methodology}

Based on prior literature, independent and dependent variables have been identified for this study. Independent variables are measured in terms of $\log$ of the amount of capital injections through credit guarantee schemes, special liquidity schemes, asset backed security schemes and asset protection schemes (Pazarbasioglu et al., 2011; NAO, 2010; Acharya \& Yorulmazer, 2007; Hryckiewicz, 2014 and Ratnovski et al., 2012). Dependant variable - bank performance is measured in terms of bank performance ratios, which are, return on assets (ROA =net income/total assets), return of equity ( $\mathrm{ROE}=$ net income/total equity) and net interest margin (NIM=net interest income/ average earning assets) (Beltratti \& Stulz, 2012; Berger \& Bouwman, 2013; Bertay et al., 2013; Kumbirai \& Webb, 2010; Yeh, 1996). Accordingly, the hypothesis (H1) of the study has been derived as follows;

H1: All the other factors being constant, government bailout has a significant influence on bank performance in bailout banks

Independent variables are measured in terms of log of the amount of capital injections through credit guarantee schemes, special liquidity schemes, asset backed security schemes and asset protection schemes (Pazarbasioglu et al., 2011; NAO, 2010; Acharya \& Yorulmazer, 2007; Hryckiewicz, 2014 and Ratnovski et al., 2012). Dependant variable bank risk taking, measured in terms of bank risk ratios, which are leverage ratio (total equity/total assets), loan ratio (net loans/total assets) and non-performing loans ratio (impaired loans/gross loans). (Dam \& Koetter, 2012; Hakenes \& Schnabel, 2010; Demirgüç-Kunt \& Huizinga, 2013; Gropp et al., 2011; Berger et al., 2016; Duchin \& Sosyura, 2014; Black \& Hazelwood, 2013; Hryckiewicz, 2014). Accordingly, the hypothesis of the study (H2) has been derived as follows; 
H2: All the other factors being constant, government bailout has a significant influence on bank risk taking in bailout banks

Capital injections data relating to the UK and Europe government bailedout banks can be found in the National Audit Office of the UK, in reports relating to financial system stability available online at www.nao.org.uk. Financial performance/risk ratios for the bailedout banks can be found in the Bankscope database. As the bailouts have been conducted during 20072009, the subsequent period from 2009 to 2015 will be considered for the study.

\subsection{Model}

A regression analysis will be conducted in order to evaluate the relationship between bailout and subsequent bank performance and risk taking. Hryckiewicz (2014), confirmed by Gropp et al. (2011), identified bank risk taking as a function of government intervention measures. Due to the effects of incentive monitoring, operating performance and risk premiums, bank performance and risk taking is expected to vary on the mechanisms used in a government bailout programme. Therefore, the model for bank performance (Per) and risk taking (Risk) for bank $\mathrm{i}$ in time period $\mathrm{t}$, will be a function of bailout measures $\mathrm{X}_{\mathrm{it}}$.

Basic model for bank performance

$$
\operatorname{Per}_{i t}=\alpha_{0}+\alpha_{1} * X_{i(t-n)}+\varepsilon_{i t}
$$

In the case of this research study, the above formula has to be expanded in order to reflect the effect of various bailout policy measures. Per $_{i t}$ will be measured using separate panel regressions for $\mathrm{ROA}_{\mathrm{it}}, \mathrm{ROE}_{\mathrm{it}}, \mathrm{NIM}_{\mathrm{it}}$. Further, $\mathrm{Per}_{\mathrm{it}}$ will be a function of $\log$ of the total capital injections (ln_Capital $\left.\mathrm{i}_{(\mathrm{t}-\mathrm{n})}\right)$ through credit guarantee scheme $\left(\mathrm{CG}_{\mathrm{i}(\mathrm{t}-\mathrm{n})}\right)$, special liquidity scheme $\left(\mathrm{SL}_{\mathrm{i}(\mathrm{t}-\mathrm{n})}\right)$, asset backed security scheme $\left(\mathrm{AB}_{\mathrm{i}(\mathrm{t}-\mathrm{n})}\right)$ and asset protection scheme $\left(\mathrm{AP}_{\mathrm{i}(\mathrm{t}-\mathrm{n})}\right)$, which are dummy variables adopting value one for usage of the scheme.

$$
\begin{aligned}
& \operatorname{Per}_{i t}\left(\mathrm{ROA}_{\mathrm{it}} / \mathrm{ROE}_{\mathrm{it}} / \mathrm{NIM}_{\mathrm{it}}\right)=\alpha_{0}+\alpha_{1} * \ln _{-} \mathrm{Capital}_{\mathrm{i}(\mathrm{t}-\mathrm{n})}+ \\
& \alpha_{2} \mathrm{CG}_{\mathrm{i}(\mathrm{t}-\mathrm{n})}+\alpha_{3} * \mathrm{SL}_{\mathrm{i}(\mathrm{t}-\mathrm{n})}+\alpha_{4} * \mathrm{AB}_{\mathrm{i}(\mathrm{t}-\mathrm{n})}+\alpha_{5} * \mathrm{AP}_{\mathrm{i}(\mathrm{t}-\mathrm{n})}+\varepsilon_{\mathrm{it}}
\end{aligned}
$$

Basic model for bank risk taking according to Hryckiewicz (2014) is;

$$
\text { Risk }_{\mathrm{it}}=\alpha_{0}+\alpha_{1} * \mathrm{X}_{\mathrm{i}(\mathrm{t}-\mathrm{n})}+\varepsilon_{\mathrm{it}}
$$

In the expanded formula, Risk $k_{i t}$ will be measured using separate panel regressions for leverage ratio $\left(\right.$ Leverage $\left._{i t}\right)$, loan ratio $\left(\operatorname{Loan}_{i t}\right)$ and non-performing loans ratio $\left(\mathrm{NPL}_{\mathrm{it}}\right)$. Further, Risk $\mathrm{it}_{\mathrm{it}}$ will be a function of $\log$ of the total capital injections (ln_Capital $\left.\mathrm{I}_{(\mathrm{t}-\mathrm{n})}\right)$ through credit guarantee scheme $\left(\mathrm{CG}_{\mathrm{i}(\mathrm{t}-\mathrm{n})}\right)$, special liquidity scheme $\left(\mathrm{SL}_{\mathrm{i}(\mathrm{t}-\mathrm{n})}\right)$, asset backed security scheme $\left(\mathrm{AB}_{\mathrm{i}(\mathrm{t}-\mathrm{n})}\right)$ and 
asset protection scheme $\left(\mathrm{AP}_{\mathrm{i}(\mathrm{t}-\mathrm{n})}\right)$ which are dummy variables, adopting value one for usage of the scheme.

$$
\begin{aligned}
& \text { Risk }_{\text {it }}\left(\text { Leverage }_{i t} / \operatorname{Loan}_{\text {it }} / \mathrm{NPL}_{\mathrm{it}}\right)=\alpha_{0}+\alpha_{1} * \ln \_ \text {Capital } \\
& \alpha_{2}(\mathrm{t}-\mathrm{n})
\end{aligned}
$$

\subsection{Measurement of data}

Financial indicators that will be included in the analysis has to be standardised "in order to create indicators that are on the same scale and to avoid some of the variables to have greater influence on the index, then due to scale measurement" (Hryckiewicz, 2014; Popovska, 2014; Petrovska \& Mihajlovska, 2013). Dependant variables will be standardized by subtracting the sample mean from the value of each individual observation in the sample for each bank and further, the difference is divided by the standard deviation of the sample for each bank. The standardisation of variables is a linear combination of the standardised value ( $\mathrm{Z}$-score) for each ratio. As an example, ROA for bank $\mathrm{i}$ at period t has been calculated as follows;

$$
\mathrm{Zr}_{\mathrm{it}}=\left(\mathrm{R}_{\mathrm{it}}-\mu \mathrm{R}_{\mathrm{i}}\right) / \sigma \mathrm{R}_{\mathrm{i}}
$$

Where; $\mathrm{Zr}_{\mathrm{it}}$ - Z-score of ROA for period $\mathrm{t}$ in bank $\mathrm{i}, \mathrm{R}_{\mathrm{it}}-$ Value of ROA for period $\mathrm{t}$ in bank $\mathrm{i} ; \sigma \mathrm{R}_{\mathrm{i}}$ - Standard deviation of the value of ROA for bank $i$; $\mu \mathrm{R}_{\mathrm{i}}$ - Mean of the value of ROA for bank i.

This is a measure of relative standing, where the positive z-scores lie above the mean, while negative z-scores below the mean (Popovska, 2014). Further, it is highlighted that the "standardization of financial indicators is often applied in the construction of composite variables, especially in financial stability or financial stress indices, such as the indices of Hanschel and Monnin (2005) cited in Popovska (2014), the National Bank of Turkey, the National Bank of Albania and others".

\subsection{The sample}

The research study focuses on the bank bailouts, which have been conducted during the subsequent period (2007-2009) of the recent financial crisis, within the United Kingdom and European Union (EU). All the banks that were bailed out by the UK government and European Union have been selected for the study (altogether 16 banks). Majorly, the UK government has bailed out four banking groups during the recent financial turmoil. Further, 12 major banks from the Euro area were selected for the study (Country of Domicile attached in Appendix C). 264 observations have been made relating to the above banks. Nationalisation and subsequent privatisations have been conducted on these banks. These banks are existing in the post bail-out period under the same name or under the privatised name. Financial 
performance and risk ratios during the post bailout period (2009-2015) were collected from the Bankscope database. Further, some of the quarterly ratios were calculated using quarterly financial statements of the selected banks. Data relating to the government interventions under credit guarantee schemes, special liquidity schemes, asset backed security schemes and asset protection schemes in the selected banks were gathered using the reports published by National Audit Office from 2009 to 2011.

\subsection{Data analysis}

Regression analysis was conducted to test the hypothesis of this study. Two hypotheses have been tested to measure the association of independent variables with the dependant variables. Hypotheses were tested using simple linear regressions (ordinary least square method) including the diagnosis tests to evaluate the regression model. In order to further confirm the results, a panel regression analysis was conducted for both hypotheses. Robustness of the results were tested with the usage of different dependant variables for performance as well as risk taking.

\subsection{Relationship between government bailouts and bank performance}

In order to test the hypothesis, $\mathrm{H}_{1}$ : All the other factors being constant, government bailouts have a significant influence on bank performance in bailout banks; the relationship between the log of the total capital flow and capital flow by several bailout packages were considered. The dependant variables used to measure performance were return on assets (ROA), return on equity (ROE) and net interest margin (NIM). Separate regressions (OLS and Panel) were conducted for dependant variables.

According to the test results, total capital flow reflects significant results relating to ROA (Table A2: regression 1) with a coefficient of -0.249098 with t statistic exceeding -1.96 . It shows a negative relationship between the log of total bailout capital flow and ROA. Kumbirai and Webb (2010) have measured bank performance in terms of ROA and obtained similar results. Although Pazarbasioglu et al. (2011) have highlighted the significance of the structure of the bailout package, the individual schemes, which are corporate guarantee schemes, liquidity support schemes, asset backed security schemes and asset protection schemes do not show any significant relationship with the ROA. A similar kind of analysis have been conducted by Hryckiewicz (2014) with equity ratio where a negative effect was observed only in terms of corporate guarantee scheme while other schemes were insignificant. Adjusted R ${ }^{2}$ is $39.87 \%$, where $39.87 \%$ of the variation of ROA is explained by the included characteristics in terms of independent variables. Further, diagnostic tests were performed to evaluate the regression model, by testing for heteroscedasticity, presence of omitted variables and normality of the model. 
The Breusch-Pagan / Cook-Weisberg test for heteroscedasticity provides a chi squared test statistic of 8.17 compared to the critical value of 12.59 . Therefore, there is no evidence to reject the null hypothesis of the constant variance of the residual. The residual is homoscedastic and there is no presence of the heteroscedasticity in the model. Ramsey RESET test was performed to test the presence of omitted variables in the model and obtained Prob $>F=0.1443$. Since $\mathrm{p}$ value is larger than $5 \%$ critical value, author fail to reject the null hypothesis, which is "the model does not have any omitted variables". Therefore, no omitted variables are present in the model. Jarque-Bera Lagrange multiplier test for normality was performed to test the normality of the residual. The chi squared value obtained is 13.00, exceeding the critical value of 5.99, rejecting the null hypothesis of residuals are normally distributed. This reflects the presence of outliers in the sample, which can be a common factor for financial performance ratios due to the high volatility.

A panel regression was performed to confirm the results between bailed out capital and ROA (Table A2: regression 2). Since it is believed that differences across the banks used for the study have some influence on the dependent variable (ROA), the random effects model has been used. Wald chi square value indicates 78.60 with probability value of 0.0000 , which is less than 0.05 . This reflects that the model has significant variables with coefficients different from zero. P value for ln_Capital variable is 0.0000 , reflecting significant results showing a negative relationship with ROA with a coefficient of -0.2491 . Results are in line with Kumbirai and Webb (2010) and Hryckiewicz (2014). However, the individual schemes, which are corporate guarantee schemes, liquidity support schemes, asset backed security schemes and asset protection schemes do not show any significant relationship with the ROA. However, the constant term is significant.

When regressing the government bailout package with the performance ratio ROE (Table A2: regression 3), log of total capital flow reflects significant results with a coefficient of -4.487936 with t statistic exceeding -1.96. It shows a negative relationship between the log of total bailout capital flow and ROE. The result is consistent with Kumbirai and Webb (2010) regarding the bank performance. However, the individual schemes, which are corporate guarantee schemes, liquidity support schemes, asset backed security schemes and asset protection schemes do not show any significant relationship with the ROE, reflecting contrasting results with Pazarbasioglu et al. (2011), while the constant is significant. Adjusted $\mathrm{R}^{2}$ is $57.25 \%$, where $57.25 \%$ of the variation of ROE is explained by the included characteristics in terms of independent variables. Further, diagnostic tests were performed to evaluate the regression model, by testing for heteroscedasticity, presence of omitted variables and normality of the model.

The Breusch-Pagan / Cook-Weisberg test for heteroscedasticity provides a chi squared test statistic of 7.81 compared to the critical value of 12.59 . Therefore, there is no evidence to reject the null hypothesis of the constant variance of the residual. The residual is 
homoscedastic and there is no presence of heteroscedasticity in the model. Further, the Ramsey RESET test was performed to test the presence of omitted variables in the model and Prob $>F=0.0800$ was obtained. Since $p$ value is larger than $5 \%$ critical value, author fail to reject the null hypothesis - "the model does not have any omitted variables". Therefore, no omitted variables are present in the model. The Jarque-Bera Lagrange multiplier test for normality was also performed to test the normality of the residual. The chi squared value obtained is 3.52 below the critical value of 5.99. Therefore, author fail to reject the null hypothesis of the model, which is "residuals are normally distributed". This reflects that there are no outlier observations in the sample.

According to the panel regression results relating to the random effects model between bailed out capital and ROA (Table A2: regression 4), Wald chi square value indicates 153.62 with probability value of 0.0000 , which is less than 0.05 . This reflects that the model has significant variables with coefficients different from zero. P value for ln_Capital variable is 0.0000 , reflecting significant results, showing a negative relationship with ROE with a coefficient of 4.487936. Results are in line with Kumbirai and Webb (2010). However, the individual schemes, which are corporate guarantee schemes, liquidity support schemes, asset backed security schemes and asset protection schemes do not show any significant relationship with the ROE although the constant term is significant.

When regressing the government bailout package with the performance ratio NIM (Table A2: regression 5), log of total capital flow reflects that insignificant results with a coefficient of 0.04878 with t statistic of -1.26 . Although Yeh (1996) and Kumbirai and Webb (2010) identify NIM as a significant performance measure, it did not provide significant results apart from showing a negative relationship between the log of total bailout capital flow and NIM. Further, the individual schemes, which are corporate guarantee schemes, liquidity support schemes, asset backed security schemes and asset protection schemes do not show any significant relationship with the NIM, reflecting contrasting results with Pazarbasioglu et al. (2011) while the constant is significant. Further, diagnostic tests were performed to evaluate the regression model, by testing for heteroscedasticity, presence of omitted variables and normality of the model.

The Breusch-Pagan / Cook-Weisberg test for heteroscedasticity provides a chi squared test statistic of 2.19 compared to the critical value of 12.59 . Therefore, there is no evidence to reject the null hypothesis of constant variance of the residual. The residual is homoscedastic and there is no presence of the heteroscedasticity in the model. Furthermore, the Ramsey RESET test was performed to test the presence of omitted variables in the model and Prob > $\mathrm{F}=0.9449$ was obtained. Since p value is larger than $5 \%$ critical value, author fail to reject the null hypothesis which says, "model does not have any omitted variables". Therefore, no omitted variables present in the model. In addition, the Jarque-Bera Lagrange multiplier test for normality was performed to test the normality of the residual. The chi squared value 
obtained is 0.35 below the critical value of 5.99 , therefore, Author fail to reject the null hypothesis which says, "the residuals are normally distributed". This reflects that there are no outlier observations in the sample.

Panel regression results relating to the random effects model (Table A2: regression 6) confirms the above regression results, with Wald chi square value of 3.83 with probability value of 0.5746 , which is above 0.05 . This reflects that the model does not have any significant variables with coefficients different from zero. P value for In_Capital variable is 0.208 , reflecting insignificant results, showing a negative relationship with NIM with a coefficient of -0.4878 . Further, the individual schemes, which are corporate guarantee schemes, liquidity support schemes, asset backed security schemes and asset protection schemes do not show any significant relationship with the NIM although the constant term is significant.

\subsection{Robustness of the results}

Out of the three performance ratios, ROA and ROE provided significant negative regression results with the log of total government bailout capital flow, proving the robustness of the results of the regression analysis conducted. However, NIM provided insignificant results for the regressions conducted. But the sign of the coefficient was negative confirming the negative, association between the government bailouts and bank performance in the post bailout period.

In order to understand the robustness of the results further, a model for crisis was developed. A dummy variable 'crisis' was added to the regressions, where it represents one for the crisis year (2008-2009) and all the other years represents zero, controlling for the crisis. According to results of the crisis model (Table A2: regression 7), crisis variable is significant with a t value of 3.32, reflecting that financial crisis has a significant effect on bank performance, while

In_Capital variable is also significant, showing a negative relationship between ROA and log of capital flow, which reflects robust results with the prior regressions. Table A2: regression 8 represents the crisis model regression summary with performance ratio ROE, crisis variable is significant with a t value of 2.44, reflecting the significant effect on bank performance due to financial crisis, while ln_Capital variable is also significant showing a negative relationship between ROE and log of capital flow, which reflects robust results. Table A2: regression 9 represents crisis model regression summary with performance ratio NIM, crisis variable is significant with a t value of 2.31, while ln_Capital variable is insignificant but shows a negative relationship between NIM and log of capital flow, which reflects robust results.

\subsection{Relationship between government bailouts and bank risk taking}

In order to test the hypothesis, $\mathrm{H}_{2}$ : all the other factors being constant, government bailout has a significant influence on bank risk taking in bailout banks, the relationship between the log of the total capital flow and capital flow under several bailout packages were considered. 
The dependant variables used to measure bank risk taking were leverage ratio (leverage), loan ratio (loan) and non-performing loans ratio (NPL). Separate regressions (OLS and Panel) were conducted for dependant variables.

When regressing the government bailout package with the risk ratio leverage (Table A3: regression 10), log of total capital flow reflects significant results with a coefficient of 0.2224266 with t statistic of 2.98 exceeding 1.96 . It shows a positive relationship between the log of total bailout capital flow and leverage. Beltratti and Stulz (2012) also have found similar results in their study, building a positive relationship with leverage. Further, Bertay et al. (2013) highlighted the importance of risk and return in bailouts. This result is consistent with the findings of Hryckiewicz (2014), as the bailout capital has increased risk in the intervened banks. However, this result contrasts with the results of Hakenes and Schnabel (2010) and Berger et al. (2016). The individual schemes, which are corporate guarantee schemes, liquidity support schemes and asset backed security schemes do not show any significant relationship with the leverage, reflecting contrasting results with Pazarbasioglu et al. (2011) but asset protection scheme shows significant results. However, Dam and Koetter (2012) has found that the structure of the bailout package is significant in their study. Adjusted $\mathrm{R}^{2}$ is comparatively low, which is $5.38 \%$, where only $5.38 \%$ of the variation of leverage is explained by the included characteristics in terms of independent variables. Further, diagnostic tests were performed to evaluate the regression model, by testing for heteroscedasticity, presence of omitted variables and normality of the model.

The Breusch-Pagan / Cook-Weisberg test for heteroscedasticity provides a chi squared test statistic of 0.59 compared to the critical value of 12.59 . Therefore, there is no evidence to reject the null hypothesis of constant variance of the residual. The residual is homoscedastic and there is no presence of the heteroscedasticity in the model. The Ramsey RESET test was performed to test the presence of omitted variables in the model and Prob $>F=0.7722$ was obtained. Since $\mathrm{p}$ value is larger than $5 \%$ critical value, author fail to reject the null hypothesis which says, "model does not have any omitted variables". Therefore, no omitted variables are present in the model. The Jarque-Bera Lagrange multiplier test for normality was performed to test the normality of the residual. The chi squared value obtained is 6.99 , exceeding the critical value of 5.99, therefore, reject the null hypothesis which says, "residuals are normally distributed". This reflects that there are outlier observations in the sample, may be due to the high volatility of leverage ratio during the post bailout period.

Panel regression results relating to the random effects model between leverage and log of capital flow (Table A3: regression 11) confirm the above regression results, with a Wald chi square value of 11.31 with probability value of 0.0455 , which is below 0.05 . This reflects that the model has significant variables with coefficients different from zero. P value for ln_Capital variable is 0.003 , reflecting significant results, showing a positive relationship with leverage with a coefficient of 0.2224266 . However, the individual schemes, which are corporate 
guarantee schemes, liquidity support schemes and asset backed security schemes do not show any significant relationship with the leverage, while asset protection schemes show a significant relationship.

When regressing the government bailout package with the risk ratio loan (Table A3: regression 12), log of total capital flow reflects significant results with a coefficient of -11.93315 with $t$ statistic of -16.83 exceeding -1.96. It shows a negative relationship between the log of total bailout capital flow and loan. This result contrasts with the result of Duchin and Sosyura (2014) as they found that bailed out banks will increase their loan portfolios creating high risk loans shifting the portfolio to high risk. But according to obtained results, this study shows a reduction in loan ratio. However, the individual schemes, which are corporate guarantee schemes, liquidity support schemes and asset backed security schemes do not show any significant relationship with the loan, reflecting contrasting results with Pazarbasioglu et al. (2011) and Dam and Koetter (2012), while asset protection schemes show a significant relationship. Adjusted $\mathrm{R}^{2}$ is high, which is $72.37 \%$, where $72.37 \%$ of the variation of loan is explained by the included characteristics in terms of independent variables. Further, diagnostic tests were performed to evaluate the regression model, by testing for heteroscedasticity, presence of omitted variables and normality of the model.

The Breusch-Pagan / Cook-Weisberg test for heteroscedasticity provides a chi squared test statistic of 0.36 compared to the critical value of 12.59 . Therefore, there is no evidence to reject the null hypothesis of constant variance of the residual. The residual is homoscedastic and there is no presence of the heteroscedasticity in the model. The Ramsey RESET test was performed to test the presence of omitted variables in the model and Prob $>$ F $=0.0920$ was obtained. Since $p$ value is larger than the $5 \%$ critical value, author fail to reject the null hypothesis, which says "model does not have any omitted variables". Therefore, no omitted variables are present in the model. The Jarque-Bera Lagrange multiplier test for normality was performed to test the normality of the residual. The chi squared value obtained is 4.98 , below the critical value of 5.99, therefore, author does not reject the null hypothesis which says, "residuals are normally distributed". This reflects that there are no outlier observations in the sample.

Panel regression results relating to the random effects model between loan and log of total capital (Table A3: regression 13) confirms the above regression results, with Wald chi square value of 295.73 with probability value of 0.0000 , which is below 0.05 . This reflects that the model has significant variables with coefficients different from zero. P value for ln_Capital variable is 0.0000 , reflecting significant results, showing a negative relationship with loans, with a coefficient of -11.93315 . This result contrasts with the result of Duchin and Sosyura (2014). However, the individual schemes, which are corporate guarantee schemes, liquidity support schemes and asset backed security schemes do not show any significant relationship with the 
loan, while asset protection schemes show a significant relationship. The constant is significant.

When regressing the government bailout package with the risk ratio NPL (Table A3: regression 14), log of total capital flow reflects significant results with a coefficient of 2.647934 with $t$ statistic of 15.66 exceeding 1.96. It shows a positive relationship between the log of total bailout capital flow and the NPL. This result is consistent with the findings of Hryckiewicz (2014), as the bailout capital has increased risk in the intervened banks. However, this result contrasts with the results of Hakenes and Schnabel (2010) and Berger et al. (2016) as they mention a reduction in risk after injection of bailed out capital. Further, the individual schemes, which are corporate guarantee schemes, liquidity support schemes, asset backed security schemes and asset protection schemes do not show any significant relationship with the NPL, showing contrasting results with Dam and Koetter (2012) and Pazarbasioglu et al. (2011). Adjusted $\mathrm{R}^{2}$ is high, which is $69.09 \%$, where $69.09 \%$ of the variation of the NPL is explained by the included characteristics in terms of independent variables. Further, diagnostic tests were performed to evaluate the regression model, by testing for heteroscedasticity, presence of omitted variables and normality of the model.

The Breusch-Pagan / Cook-Weisberg test for heteroscedasticity provides a chi squared test statistic of 6.09 compared to the critical value of 12.59 . Therefore, there is no evidence to reject the null hypothesis of constant variance of the residual. The residual is homoscedastic and there is no presence of the heteroscedasticity in the model. The Ramsey RESET test was performed to test the presence of omitted variables in the model and Prob $>F=0.9160$ was obtained. Since $\mathrm{p}$ value is larger than $5 \%$ critical value, author fail to reject the null hypothesis which says, "model does not have any omitted variables". Therefore, no omitted variables are present in the model. The Jarque-Bera Lagrange multiplier test for normality was performed to test the normality of the residual. The chi squared value obtained is 2.61 , below the critical value of 5.99. Therefore, do not reject the null hypothesis which says, "residuals are normally distributed". This reflects that there are no outlier observations in the sample.

Panel regression results relating to the random effects model between NPL and total capital flow (Table A3: regression 15) confirm the above regression results, with a Wald chi square value of 253.10 , with a probability value of 0.0000 , which is below 0.05 . This reflects that the model has significant variables with coefficients different from zero. P value for ln_Capital variable is 0.0000 , reflecting significant results, showing a positive relationship with the NPL with a coefficient of 2.647934. However, the individual schemes, which are corporate guarantee schemes, liquidity support schemes, asset backed security schemes and asset protection schemes do not show any significant relationship with the NPL, while the constant is significant. 


\subsection{Robustness of the results}

Out of the three risk ratios, leverage and the NPL provided significant positive regression results with the log of total government bailout capital flow, proving the robustness of the results of the regression analysis conducted. However, loan provided significant negative results for the regressions conducted. But the negative sign of the coefficient for loan indicates that the behaviour of bailed out banks reducing its loan portfolios still increases the risk of the bank, confirming the positive association between the government bailouts and bank risk taking in the post bailout period.

In order to understand the robustness of the results further, a model for crisis was developed. A dummy variable 'crisis' was added to the regressions, where it represents 'one' for the crisis year (2008-2009) and all the other years represent 'zero', controlling for the crisis. According to the results of the crisis model (Table A3: regression 16) the crisis variable is significant with a t value of -5.72 , reflecting that financial crisis has significant influence over risk taking, while ln_Capital variable is also significant, showing a positive relationship between leverage and log of capital flow, which reflects robust results.

Table A3: regression 17 represents the crisis model regression summary with risk ratio loan. Crisis variable is significant with a $t$ value of -3.85 , while ln_Capital variable is significant showing a negative relationship between loan and log of capital flow, which reflects robust results.

Table A3: regression 18 represents the crisis model regression summary with risk ratio NPL. Crisis variable is significant with a $t$ value of -3.07 , while ln_Capital variable is significant showing a positive relationship between NPL and log of capital flow, which reflects robust results.

\subsection{Consistency of the results to South Asia}

In order to further confirm the robustness of the study, a replication was performed using the yearly data relating to aftermath performance and risk of four South Asian banks (Three in India and one in Pakistan) which were bailed out during 2009 - 2015. The crisis model was used to reflect the crisis years for the respective banks. The three performance ratios ROA, ROE and NIM provided significant negative regression results with the log of total government bailout capital flow confirming the negative association between the government bailouts and bank performance in the post bailout period. Out of the three risk ratios, leverage and NPL provided significant positive regression results with the log of total government bailout capital flow, proving the positive association between the government bailouts and bank risk taking in the post bailout period, while confirming consistency of the results of the regression analysis conducted in relation to the UK and Europe. 


\section{Findings}

As per the discussion in the earlier chapter, the estimation results of both hypotheses are consistent with expectations and the prior literature. Out of the three performance ratios ROA and ROE provided significant negative regression results with the log of total government bailout capital flow. However, NIM provided insignificant results for the regressions conducted. But the sign of the coefficient was negative, confirming the negative association between the government bailouts and bank performance in the post bailout period. This result is consistent with the view that government interventions tend to decrease the performance due to inefficient banking structure. (Sironi, 2003; Flannery, 1998).

Further, out of the three risk ratios, leverage and NPL provided significant positive regression results with the $\log$ of total government bailout capital flow. However, loan provided significant negative results for the regressions conducted, while leverage and NPL confirm the positive association between the government bailouts and bank risk taking in the post bailout period. This result is consistent with the view that government interventions tend to increase risks in the bailed-out banks due to the incentive to reduce the market discipline (Hryckiewicz, 2014; Gropp \& Vesela, 2004).

Several reasons can be identified with regard to the decrease in performance and increase in risk in the bailed-out banks during the post bailed out period. One of the main reasons as identified in literature is, after conducting severe processes of government interventions, the bailed-out banks are more likely to undermine the market discipline, which then encourage banks to increase their risk levels. The cause for this behaviour is that the depositors perceive the bailed-out banks as government protected, thus they have no incentives to conduct a rigorous and careful process of monitoring (Baumann \& Nier, 2006).

According to the results of the study, the government bailout capital flow will exert negative effects with the bailed-out bank behaviour in terms of performance and positive effects in terms of risk taking due to the increased level of risk taking. As highlighted above, due to the subsequent effects of reducing market discipline, moral hazard considerations may take place within the bailed-out banks (Dam \& Koetter, 2012). Fahri and Tirole (2012) further confirmed this matter, as bailout regulatory policy will lead to collective moral hazard problems due to the cheap capital available to problem banks. This problem arises if one bank starts gambling; soon the other banks also follow, increasing the risk of the whole banking system. It is indicated that broader government protections and nationalisations will increase the banking sector risk individually as well as collectively. According to Hryckiewicz (2014), reduction in performance and increasing risk during post bailed out period can be due to three major reasons;

1. Reduced market discipline

2. Inefficient bank management

3. Lack of a proper restructuring process to help the bank to recover from the distressed status. 
However, according to Dell'Ariccia and Ratnovski (2012), increasing regulatory actions will be a remedy for this problem, as it is likely to attract market scrutiny, which can be a way of disciplining the bailed-out bank's management. Through appropriate policy measures, governments may initiate greater public scrutiny of the bailed-out banks during periods of financial turmoil, leading to bail outs and the post bailed out periods (Hryckiewicz, 2014).

To test the robustness of the result, several regressions were performed. When controlling for the crisis years also, the analysis provided robust results. It can be argued that the type of financial shock and the magnitude of the effects of the shock also will have significant influence on the performance and risk taking in the post bailed out period (Hryckiewicz, 2014).

According to the results, structure of the bailout package in terms of the individual bailout policy measures, which are corporate guarantee schemes, liquidity support schemes, asset backed security schemes and asset protection schemes do not show any significant influence on the bailed-out bank performance and risk. This indicates that the structure of the bailout package itself is not important in the case of bailed out banks, instead the total bailout capital flow is the only significant factor for the bailed-out banks, as the estimates on structure does not indicate a true effect on the neither performance nor risk. This cause was confirmed by Giannetti and Simonov (2013) as they assert that the amount of financial assistance received through the bailed-out policy measures influence the bank risk taking behaviour. Estimation results of the study showed no significance, may be due to the fact that individual dummies do not explicitly control the size of the total bailout capital flow injected to each bank under each scheme. Further, Dam and Koetter (2012) have argued that bank performance and risk taking in the post bailed out period is dependent on the policy measures injected to the bank by various schemes, where such information will be lacking in the case of this research study. Therefore, various schemes cannot be directly controlled, without having such bank specific information.

\subsection{Policy implications}

The findings reveal important policy implications. Firstly, the results show a significant risk increase in the banking sector due to bail outs, which is an important factor in the case of regulators' perspective. Thus, the results contribute to the current debacle, whether the governments should bail out the banks or not. Further, it creates pressure on governments to assess the true effects of government intervention, relating to the smooth functioning of the banking systems of a country and to shape up bank regulation by carefully selecting policies to be implemented. The theoretical evidence suggests that if government bailouts are crucial, then market controls and regulatory monitoring have to be aggravated (Hryckiewicz, 2014).

The next important factor to consider is that importance of government bailouts in economic perspectives. If a large bank fails in an economy, the damages will be detrimental due to the contagion effects on the financial system. If one bank fails the general public will lose the 
confidence about the whole financial system where all the borrowers and lenders will have to face the severe effects as the systemic effect will spread to the whole financial system. When the financial system is vulnerable to a crisis, it will have direct effects on domestic production due to the lack of credit, and the country will be running towards an economic recession due to the lowering output and increasing unemployment. Due to the instability that will be created on interest rates and exchange rates, the external sector will be imbalanced, affecting the international trade while severely affecting the balance of payment. In such a situation, the global outlook of a country will be negative and the foreign investments will be lowered, damaging the economy further. Therefore, the importance of bailouts to governments can be highlighted in order to overcome the negative economic impact of a financial turmoil.

Another aspect that has to be considered in relation to bank bailouts, is the moral hazard behaviour. It is argued that moral hazard behaviour of banks will be simulated when they receive government support in terms of bailout packages. Failure of a single bank will hamper the confidence in the whole banking system, and a too lenient regulator will create incentives for banks to take on excessive risk with the government interventions (Cordella \& Yeyati, 2003).

Bailing out of banks has a long history where different countries have attempted several structural reforms in order to overcome a crisis. Particularly in the US, the setting up of the Federal Reserve System in 1914 and the setting up of the Federal Deposit Insurance Corporation in 1934 are a part of structural reforms to combat bank crises. During the subsequent period of the recent turmoil, although the recovery of the global economy has been modest, the volatility in the international financial markets remained heightened. Slowing down of international trade, rising debt levels in the international markets especially in the EU area also have significantly influenced the performance of the banking sector.

Considering the macroeconomic impact of a bank crisis, several regulatory reforms have been developed to surface a crisis. With the implementation of Basel III, introducing additional capital cushion to absorb losses, reduce leverage and high liquidity, advanced stress testing and bail-in packages for relatively large problem banks can be identified as some of measures.

\section{Conclusions}

The study was conducted using the data of all the bailed-out banks within the UK and Europe bailed out by the governments during the recent financial turmoil of 2007-2009. The database facilitated the investigation of the behaviour in terms of performance and risk taking of the bailed-out banks during the post bailed out period. Two hypotheses were developed through the literature survey and tested using the regression analysis. Few conclusions can be made considering the findings of the study.

Although it is argued that government interventions in terms of bailouts are important and it helps governments to limit the negative consequences in terms of systemic risks to the 
financial systems during a financial turmoil, the estimation results reflect that bailouts are associated with subsequent reduction in performance and increase in risk during the post bailed out period. Further, literature suggests that, this can be an effect of the reduced market discipline, inefficient bank management and lack of a proper restructuring process within the bailed-out banks (Hryckiewicz, 2014). Further, a region-wise structural resolution framework can be developed and implemented, which can be used at a time of a bank crisis.

Moreover, the estimation results further revealed that the structure of the bailed-out package in terms of corporate guarantee schemes, liquidity support schemes, asset backed security schemes and asset protection schemes are not significant to the bailed-out banks, but the total capital flow is highly significant to the bailed-out banks. The evidence proved to be robust to the modifications such as controlling for the crisis years, use of different performance and risk measures to measure performance and risk. Further, results were consistent with the bailedout banks in the South Asian region as well according to the test results.

\subsection{Limitations of the study}

The main focus of the study was limited to the banks that were bailed out by the governments of the UK and Europe. The comparative effects cannot be measured compared to the nonbailed out banks, which goes beyond the "inherited risk portion" of the bailed-out banks. Therefore, the effects from the non-bailed out banks could not be controlled, which may finally have an effect on the endogeneity of the study. The difference-in-differences estimation method could have been used to compare the behaviour of non-assisted banks. The assisted banks could be separated for two-time periods, as during the time of intervention and during the post bailed out period, if a controlling group of non-assisted banks were to be included in the study. Further, due to the non-availability of scheme-specialised information of the government bailout packages, those data cannot be used in the study.

\subsection{Areas for further research}

This study was conducted considering the bailed-out banks within the UK and Europe. However, the results were consistent for the banks in the South Asian region as well. The study can further be extended, controlling for different types of financial crises in different countries, controlling for the magnitude of the financial crises, as a whole will provide more precise findings regarding the bank behaviour. Particularly, during the recent financial crisis, although the US and Europe were severely affected, Asia and Africa were not affected in that magnitude of the crisis. Therefore, a novel research study can be conducted considering the reasons for the above fact, while discussing the behaviour of Asian banks precisely during a financial crisis. Further, the study can be extended considering the macroeconomic conditions of the domicile countries, including a control group of non-bailed out banks also to the sample. 


\section{References}

Acharya, Viral V., and Tanju Yorulmazer. "Too many to fail- An analysis of time-inconsistency in bank closure policies." Journal of financial intermediation 16.1 (2007): 1-31.

Barth, Andreas, and Isabel Schnabel. "Why banks are not too big to fail-evidence from the CDS market." Economic Policy 28.74 (2013): 335-369.

Baumann, Ursel, and Nier, Erlend. "Market discipline, disclosure and moral hazard in banking." Journal of Financial Intermediation 15.3 (2006): 332-361.

Berger, Allen N., and Christa HS Bouwman. "How does capital affect bank performance during financial crises?." Journal of Financial Economics 109.1 (2013): 146-176.

Berger, Allen N., Christa HS Bouwman, Thomas Kick, and Klaus Schaeck. "Bank liquidity creation following regulatory interventions and capital support." Journal of Financial Intermediation 26 (2016): 115-141.

Beltratti, Andrea, and René M. Stulz. "The credit crisis around the globe: Why did some banks perform better?." Journal of Financial Economics 105.1 (2012): 1-17.

Bertay, Ata Can, Asli Demirgüç-Kunt, and Harry Huizinga. "Do we need big banks? Evidence on performance, strategy and market discipline." Journal of Financial Intermediation 22.4 (2013): 532-558.

Black, Lamont K., and Lieu N. Hazelwood. "The effect of TARP on bank risk-taking." Journal of Financial Stability 9.4 (2013): 790-803.

Brown, Craig O., and I. Serdar Dinç. "Too many to fail? Evidence of regulatory forbearance when the banking sector is weak." The Review of Financial Studies 24.4 (2011): 13781405 .

Cordella, Tito, and Eduardo Levy Yeyati. "Bank bailouts: moral hazard vs. value effect." Journal of Financial intermediation 12.4 (2003): 300-330.

Dam, Lammertjan, and Michael Koetter. "Bank bailouts and moral hazard: Evidence from Germany." The Review of Financial Studies 25.8 (2012): 2343-2380.

Dell'Ariccia, Giovanni, and Lev Ratnovski IMF. "Bailouts, Contagion, and Bank Risk-taking." Society for Economic Dynamics Working Paper 133 (2012).

Demirgüç-Kunt, Asli, and Harry Huizinga. "Are banks too big to fail or too big to save? International evidence from equity prices and CDS spreads." Journal of Banking \& Finance 37.3 (2013): 875-894.

Diamond, Douglas W., and Philip H. Dybvig. "Bank runs, deposit insurance, and liquidity." Journal of political economy 91.3 (1983): 401-419.

Dooley, Michael. "Can emerging economy central banks be market-makers of last resort?." BIS Paper, (2014)

Duchin, Ran, and Denis Sosyura. "Safer ratios, riskier portfolios: Banks' response to government aid." Journal of Financial Economics 113.1 (2014): 1-28. 
Farhi, Emmanuel, and Jean Tirole. "Collective moral hazard, maturity mismatch, and systemic bailouts." American Economic Review 102.1 (2012): 60-93.

Flannery, Mark J. "Using market information in prudential bank supervision: A review of the US empirical evidence." Journal of Money, Credit and Banking (1998): 273-305.

Giannetti, Mariassunta, and Andrei Simonov. "On the real effects of bank bailouts: Micro evidence from Japan." American Economic Journal: Macroeconomics 5.1 (2013): 135-67.

Gorton, Gary, and Andrew Metrick. "The federal reserve and panic prevention: The roles of financial regulation and lender of last resort." Journal of Economic Perspectives 27.4 (2013): 45-64.

Gropp, Reint, Hendrik Hakenes, and Isabel Schnabel. "Competition, risk-shifting, and public bail-out policies." The Review of Financial Studies 24.6 (2010): 2084-2120.

Gropp, Reint, and Jukka Vesala. "Deposit insurance, moral hazard and market monitoring." Review of Finance 8.4 (2004): 571-602.

Grigorian, David A., and Vlad Manole. "Determinants of commercial bank performance in transition: an application of data envelopment analysis." Comparative Economic Studies 48.3 (2006): 497-522.

Hakenes, Hendrik, and Isabel Schnabel. "Banks without parachutes: Competitive effects of government bail-out policies." Journal of Financial Stability 6.3 (2010): 156-168.

Hryckiewicz, Aneta. "What do we know about the impact of government interventions in the banking sector? An assessment of various bailout programs on bank behavior." Journal of Banking \& Finance 46 (2014): 246-265.

Kumbirai, Mabwe, and Robert Webb. "A financial ratio analysis of commercial bank performance in South Africa." African Review of Economics and Finance 2.1 (2010): 3053.

Kroszner, Randall S., Luc Laeven, and Daniela Klingebiel. "Banking crises, financial dependence, and growth." Journal of financial Economics 84.1 (2007): 187-228.

Lacker, Jeffrey M. "Fed Credit Policy: What is a Lender of Last Resort?." Journal of Economic Dynamics and Control 49 (2014): 135-138.

Mehran, Hamid, and Anjan Thakor. "Bank capital and value in the cross-section." The Review of Financial Studies 24.4 (2011): 1019-1067.

Moshirian, Fariborz. "The global financial crisis and the evolution of markets, institutions and regulation." Journal of Banking \& Finance 35.3 (2011): 502-511.

National Audit Office, (2010). Maintaining the financial stability of UK banks: update on the support schemes, National Audit Office, available online at 'https://www.nao.org.uk/report/maintaining-the-financial-stability-of-uk-banksupdate-on-the-support-schemes/'

O'hara, Maureen, and Wayne Shaw. "Deposit insurance and wealth effects: the value of being "too big to fail"." The Journal of Finance 45.5 (1990): 1587-1600. 
Pazarbasioglu, Ceyla, Mr Luc Laeven, Oana M. Nedelescu, Stijn Claessens, Fabian Valencia, Marc Dobler, and Katharine Seal. Crisis management and resolution: Early lessons from the financial crisis. International Monetary Fund, (2011).

Petrovska, Magdalena, and Elena Mucheva Mihajlovska. "Measures of financial stability in Macedonia." Journal of central banking Theory and practice 2.3 (2013): 85-110.

Popovska, Jasmina. "Modeling financial stability: The case of the banking sector in Macedonia." Journal of Applied Economics and Business 2.1 (2014): 68-91.

Sironi, Andrea. "Testing for market discipline in the European banking industry: evidence from subordinated debt issues." Journal of Money, Credit and Banking (2003): 443-472.

Yeh, Quey-Jen. "The application of data envelopment analysis in conjunction with financial ratios for bank performance evaluation." Journal of the Operational Research Society 47.8 (1996): 980-988.

Yiannaki, Mihai Simona. "Bank bailouts: lessons to learn when patience is a virtue." EuroMed Journal of Business 6.2 (2011): 192-205. 


\section{Appendices}

Table A1: Descriptive statistics

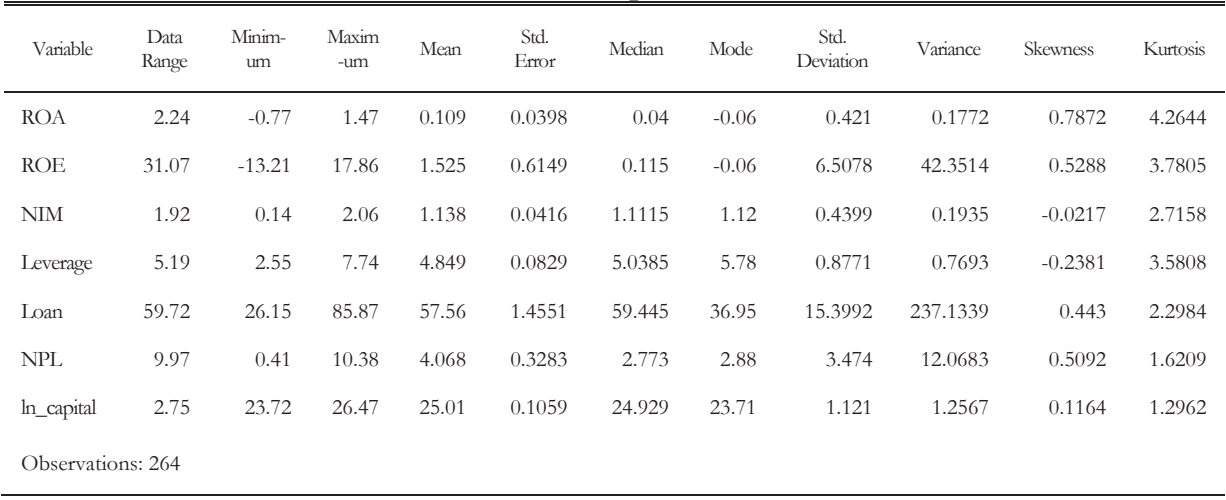

Table A2: Regression results at $95 \%$ confidence interval for relationship between government bailouts and bank performance

\begin{tabular}{|c|c|c|c|c|c|c|c|c|c|}
\hline Dependent & $\begin{array}{c}\text { ROA } \\
\text { OLS } \\
(1)\end{array}$ & $\begin{array}{c}\text { ROA } \\
\text { Panel } \\
(2)\end{array}$ & $\begin{array}{c}\text { ROE } \\
\text { OLS } \\
(3)\end{array}$ & $\begin{array}{c}\text { ROE } \\
\text { Panel } \\
(4)\end{array}$ & $\begin{array}{c}\text { NIM } \\
\text { OLS } \\
(5)\end{array}$ & $\begin{array}{c}\text { NIM } \\
\text { Panel } \\
(6)\end{array}$ & $\begin{array}{c}\text { Crisis } \\
\mathrm{ROA} \\
(7)\end{array}$ & $\begin{array}{c}\text { Crisis } \\
\text { ROE } \\
(8)\end{array}$ & $\begin{array}{c}\text { Crisis } \\
\text { NIM } \\
(9)\end{array}$ \\
\hline In_Capital & $\begin{array}{r}0.000^{* * * *} \\
(0.029)\end{array}$ & $\begin{array}{r}0.000^{* * *} * \\
(0.028)\end{array}$ & $\begin{array}{r}0.000^{* * * *} \\
(0.373)\end{array}$ & $\begin{array}{r}0.000^{* * * *} \\
(0.373)\end{array}$ & $\begin{array}{r}0.211 \\
(0.038)\end{array}$ & $\begin{array}{r}0.208 \\
(0.038)\end{array}$ & $\begin{array}{r}0.000^{* * * *} \\
(0.027)\end{array}$ & $\begin{array}{r}0.000^{* * *} \\
(0.364)\end{array}$ & $\begin{array}{r}0.229 \\
(0.037)\end{array}$ \\
\hline CG & $\begin{array}{r}0.933 \\
(0.068)\end{array}$ & $\begin{array}{r}0.933 \\
(0.068)\end{array}$ & $\begin{array}{r}0.496 \\
(0.889)\end{array}$ & $\begin{array}{r}0.495 \\
(0.889)\end{array}$ & $\begin{array}{r}0.804 \\
(0.092)\end{array}$ & $\begin{array}{r}0.803 \\
(0.092)\end{array}$ & $\begin{array}{r}0.709 \\
(0.065)\end{array}$ & $\begin{array}{r}0.725 \\
(0.878)\end{array}$ & $\begin{array}{r}0.568 \\
(0.091)\end{array}$ \\
\hline SL & $\begin{array}{r}0.782 \\
(0.072)\end{array}$ & $\begin{array}{r}0.782 \\
(0.071)\end{array}$ & $\begin{array}{r}0.976 \\
(0.937)\end{array}$ & $\begin{array}{r}0.976 \\
(0.937)\end{array}$ & $\begin{array}{r}0.616 \\
(0.097)\end{array}$ & $\begin{array}{r}0.615 \\
(0.097)\end{array}$ & $\begin{array}{r}0.960 \\
(0.068)\end{array}$ & $\begin{array}{r}0.837 \\
(0.918)\end{array}$ & $\begin{array}{r}0.730 \\
(0.095)\end{array}$ \\
\hline $\mathrm{AB}$ & $\begin{array}{r}0.298 \\
(0.072)\end{array}$ & $\begin{array}{r}0.296 \\
(0.072)\end{array}$ & $\begin{array}{r}0.371 \\
(0.946)\end{array}$ & $\begin{array}{r}0.369 \\
(0.946)\end{array}$ & $\begin{array}{r}0.643 \\
(0.098)\end{array}$ & $\begin{array}{r}0.642 \\
(0.098)\end{array}$ & $\begin{array}{r}0.570 \\
(0.070)\end{array}$ & $\begin{array}{r}0.595 \\
(0.935)\end{array}$ & $\begin{array}{r}0.909 \\
(0.097)\end{array}$ \\
\hline $\mathrm{AP}$ & $\begin{array}{r}0.425 \\
(0.074)\end{array}$ & $\begin{array}{r}0.423 \\
(0.074)\end{array}$ & $\begin{array}{r}0.759 \\
(0.970)\end{array}$ & $\begin{array}{r}0.758 \\
(0.970)\end{array}$ & $\begin{array}{r}0.198 \\
(0.100)\end{array}$ & $\begin{array}{r}0.195 \\
(0.100)\end{array}$ & $\begin{array}{r}0.512 \\
(0.071)\end{array}$ & $\begin{array}{r}0.657 \\
(0.949)\end{array}$ & $\begin{array}{r}0.235 \\
(0.098)\end{array}$ \\
\hline _Cons & $\begin{array}{r}0.000 \\
(0.696)\end{array}$ & $\begin{array}{r}0.000 \\
(0.696)\end{array}$ & $\begin{array}{r}0.000 \\
(9.073)\end{array}$ & $\begin{array}{r}0.000 \\
(9.072)\end{array}$ & $\begin{array}{r}0.017 \\
(0.943)\end{array}$ & $\begin{array}{r}0.000 \\
(0.943)\end{array}$ & $\begin{array}{r}0.001 \\
(0.086)\end{array}$ & $\begin{array}{r}0.016 \\
(8.873)\end{array}$ & $\begin{array}{r}0.023 \\
(0.925)\end{array}$ \\
\hline Crisis & - & - & - & - & - & - & $\begin{array}{r}0.000^{* * * *} \\
(0.037)\end{array}$ & $\begin{array}{r}0.000^{* * * *} \\
(1.152)\end{array}$ & $\begin{array}{r}0.001^{* * * *} \\
(0.120)\end{array}$ \\
\hline $\begin{array}{l}\text { R-squared/ } \\
\text { model } \\
\text { significance }\end{array}$ & 0.3987 & 0.0000 & 0.5725 & 0.0000 & 0.034 & 0.5746 & 0.4506 & 0.5915 & 0.0288 \\
\hline
\end{tabular}

Note: Standard errors are in the parenthesis, ${ }^{* * *} \mathrm{p}<0.01,{ }^{* *} \mathrm{p}<0.05,{ }^{*} \mathrm{p}<0.1, \ln \_$Capital stands for the $\log$ of total capital flow, CG - corporate guarantee schemes, SL - liquidity support schemes, AB - asset backed security schemes and $\mathrm{AP}$ - asset protection schemes 
Table A3: Regression results at $95 \%$ confidence interval for relationship between government bailouts and bank risk taking

\begin{tabular}{|c|c|c|c|c|c|c|c|c|c|}
\hline Dependent & $\begin{array}{c}\text { Leverage } \\
\text { OLS } \\
(10)\end{array}$ & $\begin{array}{c}\text { Leverage } \\
\text { Panel } \\
\text { (11) }\end{array}$ & $\begin{array}{c}\text { Loan } \\
\text { OLS } \\
(12)\end{array}$ & $\begin{array}{l}\text { Loan } \\
\text { Panel } \\
(13)\end{array}$ & $\begin{array}{l}\text { NPL } \\
\text { OLS } \\
(14)\end{array}$ & $\begin{array}{c}\text { NPL } \\
\text { Panel } \\
(15)\end{array}$ & $\begin{array}{c}\text { Crisis } \\
\text { Levera } \\
\text { ge } \\
(16)\end{array}$ & $\begin{array}{l}\text { Crisis } \\
\text { Loan } \\
(17)\end{array}$ & $\begin{array}{l}\text { Crisis } \\
\text { NPL } \\
(18)\end{array}$ \\
\hline In_Capital & $\begin{array}{c}0.004^{* *} \\
(0.074)\end{array}$ & $\begin{array}{c}0.003^{* *} \\
(0.075)\end{array}$ & $\begin{array}{c}0.000^{* * *} * \\
(0.708)\end{array}$ & $\begin{array}{c}0.000^{* * *} \\
(0.708)\end{array}$ & $\begin{array}{c}0.000^{* * *} \\
(0.169)\end{array}$ & $\begin{array}{c}0.000^{* k * *} \\
(0.169)\end{array}$ & $\begin{array}{c}0.002^{* *} \\
(0.065)\end{array}$ & $\begin{array}{c}0.000^{* k * k} \\
(0.667)\end{array}$ & $\begin{array}{c}0.000^{* * *} \\
(0.162)\end{array}$ \\
\hline CG & $\begin{array}{c}0.779 \\
(0.178)\end{array}$ & $\begin{array}{c}0.779 \\
(0.178)\end{array}$ & $\begin{array}{c}0.324 \\
(1.692)\end{array}$ & $\begin{array}{c}0.322 \\
(1.692)\end{array}$ & $\begin{array}{c}0.109 \\
(0.403)\end{array}$ & $\begin{array}{c}0.106 \\
(0.404)\end{array}$ & $\begin{array}{c}0.633 \\
(0.158)\end{array}$ & $\begin{array}{c}0.612 \\
(1.608)\end{array}$ & $\begin{array}{c}0.220 \\
(0.392)\end{array}$ \\
\hline SL & $\begin{array}{c}0.703 \\
(0.188)\end{array}$ & $\begin{array}{c}0.703 \\
(0.188)\end{array}$ & $\begin{array}{c}0.635 \\
(1.783)\end{array}$ & $\begin{array}{c}0.634 \\
(1.783)\end{array}$ & $\begin{array}{c}0.154 \\
(0.425)\end{array}$ & $\begin{array}{c}0.151 \\
(0.425)\end{array}$ & $\begin{array}{c}0.399 \\
(0.165)\end{array}$ & $\begin{array}{c}0.820 \\
(1.681)\end{array}$ & $\begin{array}{c}0.090 \\
(0.411)\end{array}$ \\
\hline $\mathrm{AB}$ & $\begin{array}{c}0.713 \\
(0.190)\end{array}$ & $\begin{array}{c}0.712 \\
(0.189)\end{array}$ & $\begin{array}{c}0.663 \\
(1.799)\end{array}$ & $\begin{array}{c}0.662 \\
(1.799)\end{array}$ & $\begin{array}{c}0.641 \\
(0.429)\end{array}$ & $\begin{array}{c}0.640 \\
(0.429)\end{array}$ & $\begin{array}{c}0.642 \\
(0.168)\end{array}$ & $\begin{array}{c}0.296 \\
(1.713)\end{array}$ & $\begin{array}{c}0.994 \\
(0.418)\end{array}$ \\
\hline AP & $\begin{array}{c}0.044 \\
(0.195)\end{array}$ & $\begin{array}{c}0.042 \\
(0.194)\end{array}$ & $\begin{array}{c}0.035 \\
(1.846)\end{array}$ & $\begin{array}{c}0.033 \\
(1.845)\end{array}$ & $\begin{array}{c}0.054 \\
(0.440)\end{array}$ & $\begin{array}{c}0.051 \\
(0.440)\end{array}$ & $\begin{array}{c}0.047 \\
(0.170)\end{array}$ & $\begin{array}{c}0.015 \\
(1.738)\end{array}$ & $\begin{array}{c}0.066 \\
(0.424)\end{array}$ \\
\hline _Cons & $\begin{array}{c}0.876 \\
(1.819)\end{array}$ & $\begin{array}{c}0.870 \\
(1.819)\end{array}$ & $\begin{array}{c}0.000 \\
(17.25)\end{array}$ & $\begin{array}{c}0.000 \\
(17.26)\end{array}$ & $\begin{array}{c}0.000 \\
(4.118)\end{array}$ & $\begin{array}{c}0.000 \\
(4.118)\end{array}$ & $\begin{array}{r}0.000 \\
(1.597)\end{array}$ & $\begin{array}{c}0.000 \\
(16.24)\end{array}$ & $\begin{array}{c}0.003 \\
(3.965)\end{array}$ \\
\hline Crisis & - & - & - & - & - & - & $\begin{array}{c}0.000^{* * * *} \\
(0.207)\end{array}$ & $\begin{array}{c}0.000^{* k * k *} \\
(2.108)\end{array}$ & $\begin{array}{c}0.000^{* * * *} \\
(0.515)\end{array}$ \\
\hline $\begin{array}{l}\text { R_Squared/ } \\
\text { Model } \\
\text { Significance }\end{array}$ & 0.538 & 0.045 & 0.724 & 0.000 & 0.690 & 0.000 & 0.272 & 0.755 & 0.714 \\
\hline
\end{tabular}

Note: Standard errors are in the parenthesis, ${ }^{* *} \mathrm{p}<0.01,{ }^{*} \mathrm{p}<0.05,{ }^{*} \mathrm{p}<0.1, \ln \_$Capital stands for the log of total capital flow, CG - corporate guarantee schemes, SL - liquidity support schemes, AB - asset backed security schemes and AP - asset protection schemes 
Figure A1: Average return on assets (ROA), Average return on equity (ROE), Average net interest margin (NIM), Average Leverage, Average loan ratio and Average non-performing loan ratio over 2010 -2015 period for the bailed out banks in UK and Europe.

Average ROA

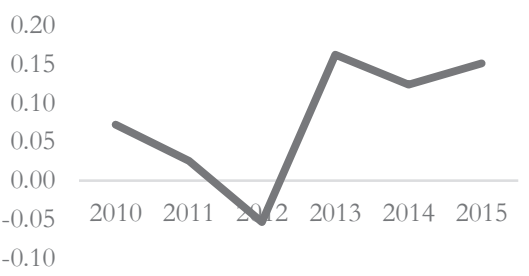

Average Net Interest Margin

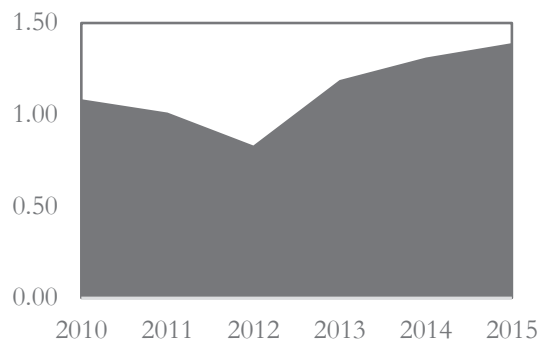

Average Leverage

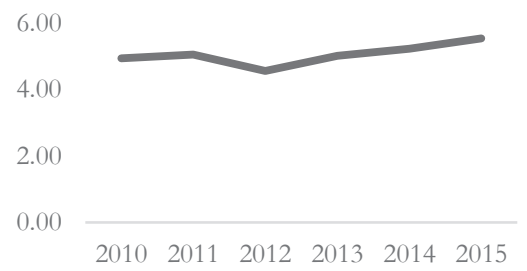

Average ROE

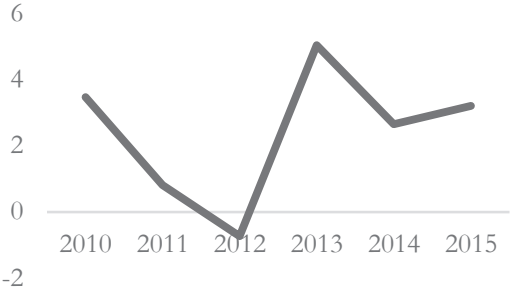

Average Leverage

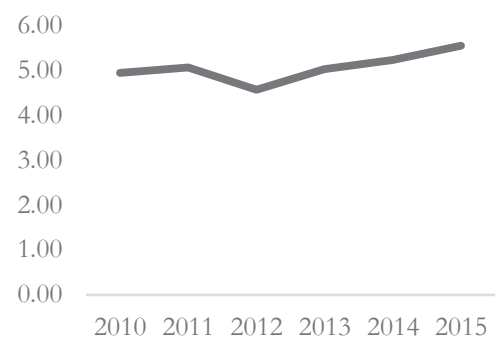

Average Non-Performing Loan Ratio

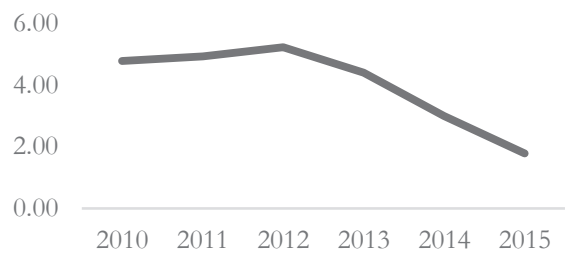

Source: Bankscope data 
Figure A2: Scheme wise total capital flow from the UK and EU governments to the bailed-out banks

Capital Flow in $£$, billions

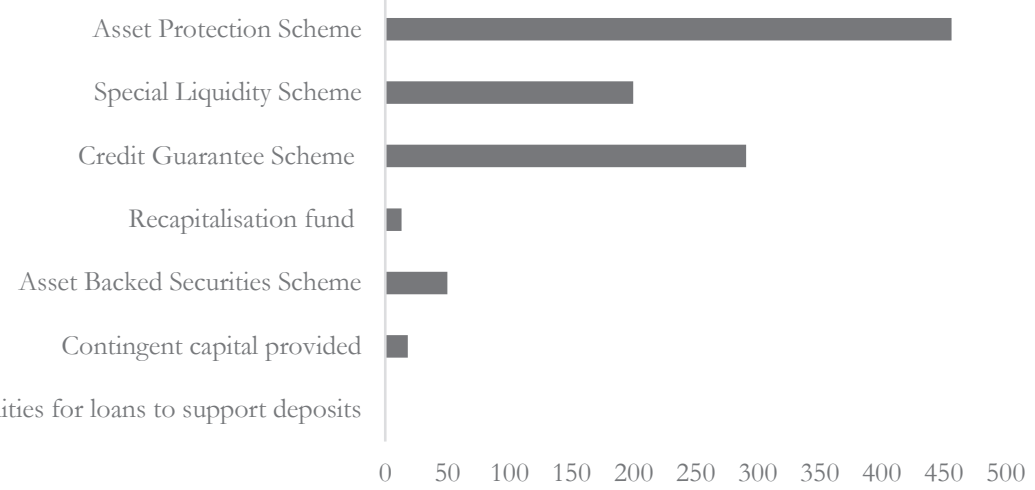

Source: National Audit Office of UK

Table A4: Domicile Countries of selected banks

\begin{tabular}{ll}
\hline \hline United Kingdom & \\
\hline European Union & Germany \\
& Austria \\
& France \\
& Greece \\
& Ireland \\
& Portugal \\
& Finland \\
& Poland \\
& Spain \\
\hline South Asia & India \\
& Pakistan \\
\hline
\end{tabular}

